\title{
Urgences
}

\section{Soyez scripteur...}

\section{Sonia Talbot}

Numéro 13, mars 1986

\section{Éclats d'atelier}

URI : https://id.erudit.org/iderudit/025207ar

DOI : https://doi.org/10.7202/025207ar

Aller au sommaire du numéro

\section{Éditeur(s)}

Urgences

\section{ISSN}

0226-9554 (imprimé)

1927-3924 (numérique)

Découvrir la revue

Citer ce document

Talbot, S. (1986). Soyez scripteur... Urgences, (13), 26-26.

https://doi.org/10.7202/025207ar

Ce document est protégé par la loi sur le droit d'auteur. L'utilisation des services d'Érudit (y compris la reproduction) est assujettie à sa politique d'utilisation que vous pouvez consulter en ligne.

https://apropos.erudit.org/fr/usagers/politique-dutilisation/ 


\section{Sonia Talbot}

Soyez scripteur. Trouvez la structure de ce spectre.

Tentez de voir au-delà de cette splendeur immobile habillée d'un seul tee-shirt de satin. Scrutez ce trésor. Traversez sa transparence. Son talent ne réside qu'en sa façon de vous transformer. Tantôt sultan, mais souvent terrorisé. Surtout sortez tranquille de cette transe. Triomphez de sa senteur de santal qui vous rend semblable à un terrier; un skye-terrier qui ne vivrait que par la tension du bas de son torse.

Soudain, comme sorti des stratus, Satie se fait entendre. Tendez l'oeil pour voir s'animer la statue. Sitôt vue, toussez un peu pour rendre compte de votre indifférence malgré le fait que la sculptée ait fait disparaître son tissu pour ne garder qu'un sautoir serti de schiste qu'elle s'amuse à faire sauter entre ses deux seins.

Tracas, n'est-ce pas?

SANCTUS

LE SOT NY A VU OU'UN STRIP-TEASE MENTAL BOTANIQUE. 